DOI:

\title{
LINGUO-METHODOLOGICAL ASPECT OF OVERCOMING INTERFERENCE IN TEACHING FOREIGN STUDENTS A SECOND NON-NATIVE LANGUAGE
}

\author{
Tetiana Krech \\ Candidate of Philological Sciences, Professor \\ Kharkov national university of civil engineering and architecture \\ (Kharkov, Ukraine) \\ e-mail: tatianakrech@gmail.com \\ Irina Milieva \\ Candidate of Philological Sciences, Associate Professor \\ Kharkov national university of civil engineering and architecture \\ (Kharkov, Ukraine) \\ e-mail: mileva_i@ukr.net
}

\begin{abstract}
Target setting of _this article is to identify the most significant pain points associated with the peculiarities of the manifestation of interference in closely related Slavic languages. The article experimentally identified and described the typology of difficulties caused by the peculiarities of interlanguage interference of closely related languages, given linguistic and methodical recommendations for overcoming them. Interlingual interference covers all language levels, this is especially pronounced at the phonetic level, since there are significant differences in the system of vocalism and consonantism. At the grammatical level, there is a difference in Russian and Ukrainian nouns on the basis of gender and number. One of the possible helpers in overcoming interference is an active educational vocabulary, which should become an assistant in speech production. The teacher requires close attention and differences in the norms of language etiquette in the Russian and Ukrainian languages.
\end{abstract}

Keywords: interlanguage interference, language level, educational vocabulary, norms of language

\section{ЛИНГВОМЕТОДИЧЕСКИЙ АСПЕКТ ПРЕОДОЛЕНИЯ ИНТЕРФЕРЕНЦИИ В ОБУЧЕНИИ ИНОСТРАННЫХ СТУДЕНТОВ}

\author{
Татьяна Васильевна Креч \\ Кандидат филологических наук, профессор \\ Харьковский национальный университет строительства и архитектуры \\ (Харьков, Украина) \\ e-mail: tatianakrech@gmail.com \\ Ирина Владимировна Милиева \\ Кандидат филологических наук, доцент \\ Харьковский национальный университет строительства и архитектуры \\ (Харьков, Украина) \\ mileva_i@ukr.net
}

\begin{abstract}
Аннотация. Украинско-русское двуязычие является важным признаком языковой ситуации в Украине. Преподавателифилологи прилагают значительные усилия, чтобы мотивировать иностранных студентов к добросовестному изучению украинского языка. Нарушение языковых и речевых норм украинского языка из-за переноса приобретенных знаний и навыков русского происходят практически на всех структурных уровнях языка. Интерференция проявляется, начиная с формирования слухо-произносительных навыков и заканчивая нарушением норм лексической и грамматической сочетаемости в речепроизводстве. Исследуя лингвометодический аспект интерференции близкородственных языков при обучении иностранных студентов, авторы дают практические рекомендации по ее преодолению.
\end{abstract}

Ключевые слова: межъязыковое вмешательство, уровень языка, образовательная лексика, нормы языка

INTRODUCTION. This article provides an analysis of the features of teaching a second non-native language in the context of a closely related bilingualism.

Despite the fact that official Ukrainian Studies usually consider Ukraine a single-level and monolingual state, it must be admitted that Ukrainian-Russian bilingualism is a system-forming feature of the linguistic situation in most Ukraine regions.

If individual bi- and polylingualism enriches the linguistic personality, expands its linguistic and cognitive horizons (let's recall the common quote attributed to J. Goethe: «As many languages you know, as many times you are a human being»), then societal bilingualism often becomes a serious issue in language production, sometimes even becoming «an excessive and unnatural phenomenon» (Gayovich), which destroys the basis of linguistic identity, although it is indeed the linguistic factor in combination with cultural identity that is key in the formation of national self-awareness.

In this article, we propose to outline the most significant pressure points associated with interference effects in closely related Slavic languages. The study is novel in that it describes interference effects in the context of foreign students studying Ukrainian with previous acquisition of Russian, which causes a triple overlay: native - Russian (systematically different) and Russian - Ukrainian (closely related). 
LITERATURE REVIEW. Analysis of publications on the subject suggests that interference effects in closely related and systematically different languages are multidimensional, extensive, and affect all levels of the compared languages.

Suffice it to recall the studies by Kh. Agitev, V. Admoni, Yu. Apresian, A.Balzeg-Shram, G. Schumacher, L. Barannikova, N. Baskakov, L. Bloomfield, Baudouin de Courtenay, M. Bulakov, L. Bulakhovsky, U. Weitreich, E. Vereshchagin, V. Vinogradov, B. Gavranek, V. Gak, B. Gornunga, Yu. Zhlukhtenko, L. Zilberman, T. Iliashenko, D. Imedadze, R. Slimchuk, M. Kopylenko, V. Kostomarov, M. Kochergin, A. Kunin, A. Lyubarskaya, M. Mikhailov, V. Moskovich, E. Passov, A. Reitsak, V. Rosenzweig, A. Rosetti, V. Rusanivsky, S. Semchipsky, E. Sapira, V. Stolbunova, A. Suprun, M. Uspensky, F. Filin, E. Haugen, N. Shoinsky, A. Shirokova, D. Shmelev, G. Shukhardt, V. Shcherba, G. Lkobeon.

The purpose of this article is to describe interference effects at all levels of closely related Russian and Ukrainian in order to minimize the errors in language produced by foreign students who are in a difficult linguistic situation of learning a second non-native language.

RESEARCH METHODS. The article experimentally identified and described the typology of difficulties caused by the peculiarities of interlanguage interference of closely related languages, given linguistic and methodical recommendations for overcoming them.

RESULTS AND DISCUSSIONS. In order to classify interference effects with the aim to describe them linguomethodologically and provide recommendations for overcoming them, we conducted a preliminary analysis of the features of Ukrainian-Russian bilingualism.

It is no coincidence that at the 9th International Linguistic Congress the issue of bilingualism, which was long underestimated or not considered at all, was proclaimed one of the central problems of linguistics (Yakobson 1965).

Bilingualism as a complex and ambiguous phenomenon is studied by different sciences from different perspectives, which each time is determined by the goals and objectives of a particular bilingual study.

Here, bilingualism is considered as a fact contributing to the comprehensive development of the individual, in contrast to the point of view on bilingualism common in foreign sociolinguistics as a temporary, transient phenomenon that differs from the natural state of using a single language: «The situation of bilingualism in and of itself scares away traditionally-minded linguists» (Martine 1972: 84).

Ukrainian-Russian bilingualism has its own characteristic aspects, which is a consequence of the genetic, structural and areal proximity of two closely related languages.

Foreign students, who have just mastered Russian at a certain level, find themselves in a linguistic situation, which makes them master another non-native - Ukrainian - language, closely related to the previously learned Russian and systematically different from their native language.

That is why it has been repeatedly proved that when learning a new foreign language one should not use an intermediate language: triple translation (for example, Ukrainian - Russian - Persian) prevents a foreign student from directing all their mental capabilities and attention to the study of the semantic and structural features of the language that they are beginning to learn. Therefore, to systematize the input, it is recommended to use the demonstration (subjective, pictorial, motor), interpretation, and context techniques (Antoniv, 2010). But such a «monolingualism» in the classroom, of course, would have better «worked» if students would also hear the Ukrainian language in unofficial communication (as in the territory of Western Ukraine). Daily use of the Russian language in informal situations leads to a slowdown in learning Ukrainian, lowering of its status, mixing of grammatical forms, errors in the use of vocabulary, orthoepic errors, etc.

In view of this, as an object of research we chose the aspect of bilingualism, which gives an opportunity to reveal the minimum knowledge necessary for foreign students to communicate, perform certain functions at the domiciliary, professional, and sociocultural level, which necessitates the determination of the ratio of monolingual and bilingual factors in the textbooks created for students of this category.

The study of the features of Ukrainian-Russian bilingualism has led us to the conclusion that of the existing two types of linguistic interference, the direct (or explicit) one is of particular relevance, which, unlike the indirect (or hidden) one, is shown as violation of the language structure, which is associated with the specifics of functioning and interpenetration of closely related languages. In any case, this process is characterized by a bilateral orientation, affecting the deepest structural layers in both language systems.

Foreign students studying in Ukraine and choosing Russian as their language of instruction also study Ukrainian as a Foreign Language as a compulsory subject.

Here, all negative effects associated with interference are most pronounced. Despite the similarity of closely related languages at all structural levels, it is precisely this similarity that constitutes a «serious danger» (Muras, 2007, p. $258-261)$ to foreign students, as the inability to distinguish these features, the unconscious desire to use the elements of the language that they have mastered while learning the Russian language often leads to numerous mistakes and inaccuracies.

From our point of view, a comparative linguistic description of the investigated interference effects is necessary for diagnosing and predicting errors in speech practice of foreign students studying Ukrainian as a second non-native language, and determining the typology of difficulties and recommendations for overcoming them.

At the same time, the close connection of the methodology with linguistics in this process is an indisputable fact for us, since to successfully overcome interference, data from linguistics, psycholinguistics and psychology are necessary.

The connection between methodology and linguistics is also showed in the fact that only when utilizing the results of a comparative study of closely related languages in educational materials (textbooks, teaching aids, 
dictionaries) can all the advantages hidden in the linguistic experience of bilinguals, and in our case polylinguals, be achieved. On the other hand, the current level of development of linguistic methodology makes us turn to the recording and analysis of errors as a reliable means of objectively evaluating the processes occurring in the linguistic consciousness of a bilingual as a result of interlanguage contact. At the same time, this makes it possible to establish observation of the process of switching foreign students from one language to another, to make far-reaching linguistic conclusions, to outline the linguodidactic parameters of the necessary teaching materials, in particular, to determine the lexical-graphic parameters of multilingual educational dictionaries.

In foreign linguistics, there are sometimes doubts that a comparative analysis of the grammatical structure of two languages can predict the degree of difficulty in mastering the forms of the language being studied (Baudouin de Courtenay, Weintreich et al.)

Our observations allow us to conclude that many difficulties associated with the acquisition by foreign students of a second non-native closely related language, which is Ukrainian in the context of Russian being studied as a specialty language, are due to the features of inter- and intra-lingual interference effects.

In this regard, it is necessary to define the term «interference» from the standpoint of linguodidactics. In psychology, transfer, which in essence is interference, is defined as "a complex phenomenon of the human psyche, the hidden mechanism of which allows a person not only to use his knowledge, skills, and expertise in mental and motor activity, but also to transfer them to the newly acquired knowledge and skills (Psiholinhvisticheskye voprosy 1972; Salistra 1966).

The transfer process is hidden from direct observation, but can be inferred from its results.

Usually, when teaching students a non-native language in the context of closely related Ukrainian-Russian bilingualism, students successfully use their knowledge from their mother tongue (Salistra 1966). For foreign students learning second non-native language, the transfer of knowledge is a much more difficult process, for it is based on language universals, which are usually regarded as "patterns common to all languages or for their absolute majority" (Novikov 1976:10; Zylberman 1972:22-23).

The issue of transfer is much more complicated in linguodidactics, since here the transfer is already considered as a combination of linguistic and individual psychological factors. Linguistic factors are a reflection of the typology of similarities and differences of the compared languages, and individual psychological ones are manifested in the individual's facility for languages, in the features of their past language experience (Psiholinhvisticheskye voprosy, 1972 , p. 88), resulting in a bilingual, and in our case a polylingual, developing the «feel of language», which is expressed in the ability to use language means without resorting to knowledge of the language (Shubin1972: 43-44).

In our case, inter-lingual interference covers all levels of the compared languages.

In order to accumulate a «negative» language material, we conducted an ascertaining experiment, which allowed us to establish a typology of difficulties in the acquisition of Ukrainian by foreign students caused by interference.

At the phonetic level, interference is shown already at the level of the formation of hearing and pronunciation skills. Despite the fact that phonemic components of Russian and Ukrainian are similar, there is still a group of vowels and consonants that do not coincide (Shpitko 2010). Thus, in Ukrainian, the phoneme /o/ is always represented by an invariant [o], only in a certain position we observe [ $\mathrm{o}^{\mathrm{y}}$ ]. Unlike Russian, the Ukrainian phoneme /o/ in a weak position is never represented by non-full variants and does not come close to [a], which should be brought to attention of foreign students when performing phonetic exercises.

When introducing the Russian consonantism to foreign students, a lot of effort is needed to develop the pronunciation skills of the phoneme / $\mathbf{\iota}$, which is always soft in Russian. These previously acquired skills are automatically transferred by students to the Ukrainian orthoepic system, in which the phoneme / $\mathrm{\Psi} /$, as a sibilant, is always hard.

A significant difficulty for foreign students learning Ukrainian in the context of previously studied Russian is the correct pronunciation of a fricative sound $[\Gamma]$, which exists in most languages formed on a Slavic basis. Students try to pronounce it as a guttural voiced sound, similar to the one in Russian. The teacher should choose the right exercises to strengthen the root of the tongue and the back of the throat, and then help develop the pronunciation skills for this sound. These skills can be reinforced by pronouncing tongue twisters with students: Галасливі гави й галки в гусенят взяли скакалки; Гусенята їм телточуть, щуо й вони скакати хочуть; оr: Гуска грає на гітарі, телтотить гусак гагарі; Горобеиь гука грака, Гава гатить гопака.

Interference with Russian is shown also when pronouncing words with the letter "щ", which in Ukrainian, unlike Russian, always means two solid sounds - [шч]: [шчоб], instead of [що]; [шчирий], instead of [щирий].

And there are a lot of such examples at the phonetic level, which requires a systematic work - measured linguistically and methodically - from a teacher.

At the grammatical level, the difference in Russian and Ukrainian nouns on the basis of gender and number is quite notable. For example, «собака» (Ukrainian - masculine, Russian - feminine); «путь» (Ukrainian - feminine, Russian - masculine), «посуд - посуда» (Ukrainian - masculine, Russian - feminine), «меблі - мебель» (Ukrainian plural, Russian - singular), «двері - дверь» (Ukrainian - plural, Russian - singular, feminine).

Foreign students who have already acquired communication skills in Russian and proficiency in its lexical means, use their knowledge to understand the lexical system of Ukrainian. That said, a part of the vocabulary is common, has the same meaning and sound in both languages. Words such as «два», «ручка», «губа» can be used as «transpositional material that facilitates the understanding and activation of the vocabulary of a student who begins to learn Ukrainian» (Metodyka vykladannia...). Much more difficult to master are the words that: a) match the letter 
structure, but differ in pronunciation («лист», «студент», «книга», «колектив»); b) are distinguished by one or two signs (both spelling and phonetically), but are also understandable («стіл», «ніс», «вухо», «волосся»).

Words that are similar in sound but have different semantics also cause great difficulties, which results in confusion and generates errors in language production among foreign students. For example, the wоrd вродливий in Ukrainian means «beautiful», and the Russian lexeme similar in sound «уродливьіи» has the antonymic meaning «very ugly», which semantically corresponds to the Ukrainian «потворний»; the Ukrainian баня semantically corresponds to the Russian купол, and the Russian баня to the Ukrainian лазня. There are many examples like this, and they testify that phonetically similar words even in closely related Ukrainian and Russian may be non-identical and even opposite in semantics.

Inter-lingual interference also affects the level of inter-lingual homonymy: so, the Ukrainian вклонитися meaning «to bow, to greet» in Russian corresponds to the verb уклониться meaning «to avoid, to evade», or the Ukrainian лишитися meaning «to stay, not to leave» corresponds to the Russian лишиться meaning «to lose».

Interference is also shown at the lexical-grammatical level as violation of the norms of lexical and grammatical compatibility, causing errors that the teacher should pay attention to.

Often, foreign students use word combinations не дивлячись на обставини instead of the normative незважаючи на обставини, здавати екзамен instead of складати іспит (екзамен), ие до мене не відноситься instead of це мене не стосується.

A certain role in provoking errors in language production is played by the use of lexical calque, which results in expressions like: це являється прикладом instead of це є прикладом, це лишній раз доказує instead of це зайвий раз доводить, послати заказним листом instead of надіслати рекомендованим листом, дошка об'яв instead of дошка оголошень.

The same loan translation affects the grammatical level. This is well demonstrated by the example of the formation of superlative adjectives, for example, the use of the word combination самий відомий спеиіаліст instead of найвідоміший спеціаліст. This category of difficulty also includes the use of certain active participles unusual for Ukrainian, e.g. the common завідуючий кафедрою instead of the Ukrainian завідувач кафедри.

Differences in the features of closely related language systems can also be observed in speech etiquette, which is especially important in language acquisition by foreign students.

This and the presence of clipped forms of greetings in Ukrainian: добридень, добривечір, на добраніч, which are absent in Russian.

Essential differential sign of the speaking etiquette of Ukrainians is the use of a vocative case for addressing someone, e.g Надіс Петрівно, Марино, пане лікарю.

Above, we gave some recommendations on a possible system of exercises aimed at removing the difficulties caused by inter-lingual interference.

A bilingual, and even better a trilingual, active-type educational dictionary with anti-interference orientation should undoubtedly be of help, and can and should become a reliable assistant in language production.

It should be remembered that if a native speaker often uses the dictionary as an encyclopedic source, a source of replenishment of their linguistic knowledge, the foreign student, caught in the linguistic environment of their second non-native language, uses the dictionary hoping to acquire an assistant in language production and construction of statements, which gives answers to many questions revealing grammatical specifics of the studied language, features of lexical and grammatical compatibility of lexical units, and determines the set of discourses revealing denotative and connotative possibilities of lexical units.

In the described linguistic situation, the description of lexical units in the educational dictionary should be preceded by the study of features of Ukrainian-Russian bilingualism, which we, using the terminology of L. Shcherba, define as «autonomous, pure from the perspective of psycholinguistics, and marked by intensive contacts and interlingual connections from the standpoint of linguistics» (Shcherba 1974: 19).

It is no coincidence that in his preface to the Russian-French dictionary, one of the outstanding theorists and practitioners of lexicography L. Shcherba wrote that «there can be no two identical bilingual dictionaries for native speakers and for a person for whom this language is not native» (Shcherba, 1974: 17-18).

CONCLUSION. In summary, we tried to give a linguo-methodological assessment of the linguistic situation in which foreign students studying non-native systematically different Russian language have to learn a second - closely related to Russian - Ukrainian language.

Our practical experience of working with such an audience allowed us to experimentally determine the typology of difficulties caused by inter-lingual interference affecting all structural levels of the languages being studied.

We hope that recommendations outlined in the article will help to overcome the arising difficulties and make the process of teaching foreign students a second non-native language easier and more successful.

\section{LIST OF REFERECES}

Antoniv, O. (2010). Hramatychnyi material u dystantsiinomu kursi ukrainskoi movy yak inozemnoi [Grammatical material in the distance course of the Ukrainian language as a foreign language]. Teoriia i praktyka vykladannia ukrainskoi movy yak inozemnoi. Vyp. 5. $128-136$.

Haiovych, H. Interferentsiia i surzhyk yak naslidky movnoi vzaiemodii (na prykladi ukrainsko-rosiiskykh movnykh kontaktiv) [Interference and surzhik as consequences of linguistic interaction (on the example of Ukrainian-Russian linguistic contacts)]. http://www.philology.kiev.ua/library/zagal/Movni_i_konceptualni_2012_41_1/224_233.pdf 
Zylberman, L.Y. (1972). Interferentsyia yazykov i metodika prepodavanyia inostrannoho yazyka na osnove rodnoho [Intervention of languages and the method of teaching a foreign language on the basis of native language]. Prepodavanyia inostrannykh yazykov i eho linhvisticheskye osnovy. Moskva: Nauka, 20 - 34.

$\begin{array}{lllllll}\text { Martine, } & \text { A. (1972). } & \text { Rasprostranenie } & \text { yazyikov lingvistika }\end{array}$ language distribution and structural linguistics] / Novoe v zarubezhnoy lingvistike. Moskva. Vyp 6.

Metodyka vykladannia ukrainskoi movy [Methodology of teaching the Ukrainian language]. www. studfiles.ru/preview/5537864/page:13/ 8

Muras, A. (2007). Vykladannia ukrainskoi movy yak inozemnoi v universyteti imeni Adama Mitskevycha v Poznani [Teaching Ukrainian as a Foreign Language at the Adam Mickiewicz University in Poznan]. Teoriia i praktyka vykladannia ukrainskoi movy yak inozemnoi. Vyp. 2. $258-261$.

Novikov, L.A. (1974). Russkyi yazyk kak ynostrannyi y osnovnye voprosy eho opysanyia [Russian as a foreign language and the main questions of its description]. Russkyi yazyk za rubezhom. № 4.

Psiholinhvisticheskye voprosy obuchenyia inostrantsev russkomu yazyku (1972) [Psycholinguistic issues of teaching foreigners to the Russian language]. Moskva: Izd-vo MHU.

Salistra, S.P. (1966). Ocherki metodov obucheniya inostrannym yazykam [Essays on methods of teaching foreign languages]. Moskva: Vyssh. shk. $251 \mathrm{s.}$

Shpitko, I. M. (2010). Fonetychna interferentsiia v informatsiinomu prostori Ukrainy [Phonetic interference in the information space of Ukraine]. Doslidzhennia z leksykolohii i hramatyky ukrainskoi movy. Vyp. $9.323-331$.

Shubin, E.R. (1972). Pozitivnye i negativnye aspekty vliyaniya pevogo yazyka na ovladenie vtorym na razlichnyh urovnyah yazykovoj sistemy [Positive and negative aspects of the influence of the speaker language on mastering the second on different levels of the language system]. Inostrannye yazyki v shkole. № 5. 27 - 32 .

Shcherba, L. V. (1974). Predislovie k bol'shomu russko-francuzskomu slovaryu: YAzykovaya sistema i rechevaya deyatel'nost' Foreword to the large Russian-French dictionary: The language system and speech activity. Moskva: Nauka. $17-23$.

Yakobson, R. (1965). Itogi IH Mednarodnogo kongressa lingvistov [the results of the international congress of linguists]. Novoe $\mathrm{v}$ zarubezhnoy lingvistike. Moskva, Vyp. 4.

\section{For citation:}

Krech Tetiana \& Milieva Irina (2019) LINGUO-METHODOLOGICAL ASPECT OF OVERCOMING INTERFERENCE IN TEACHING FOREIGN STUDENTS A SECOND NON-NATIVE LANGUAGE // International Scientific-Pedagogical Organization of Philologists “WEST-EAST” (ISPOP). Scientific Journal WEST-EAST. Vol 2/1 N1 (October, 2019). pp. 105-109. doi:

\section{Для цитирования:}

Креч Т. В., Милиева И. В. (2019) ЛИНГВОМЕТОДИЧЕСКИЙ АСПЕКТ ПРЕОДОЛЕНИЯ ИНТЕР-ФЕРЕНЦИИ В ОБУЧЕНИИ ИНОСТРАННЫХ СТУДЕНТОВ // International Scientific-Pedagogical Organization of Philologists “ WEST-EAST ” (ISPOP) . Scientific Journal WEST-EAST. Vol 1/1 N1 (October, 2019). C. 105-109. doi:

\section{Information about the authors:}

Krech Tetiana - Candidate of Philological Sciences, Professor, Department of Ukrainian language and language training for foreign citizens, Head of the Department of Ukrainian language and language training for foreign citizens, Kharkov, Ukraine e-mail: tatianakrech@gmail.com

Milieva Irina - Candidate of Philological Sciences, Associate Professor, Kharkov national university of civil engineering and architecture, Department of Ukrainian language and language training of foreign citizens, Kharkov, Ukraine.

e-mail:mileva i@ukr.net

\section{Сведения об авторах:}

Креч Татьяна Васильевна - кандидат филологических наук, профессор, Харьковский национальный университет строительства и архитектуры, кафедра украинского языка и языковой подготовки иностранных граждан, заведующая кафедрой украинского языка и языковой подготовки иностранных граждан, Харьков, Украина.

e-mail: tatianakrech@,gmail.com

Милиева Ирина Владимировна - кандидат филологических наук, доцент,

Харьковский национальный университет строительства и архитектуры доцент кафедры украинского языка и языковой подготовки иностранных граждан, Харьков, Украина.

e-mail:mileva_i@ukr.net 